\title{
Estimation of the phytoplankton productivity in three Estonian lakes
}

\author{
Tuuli Kauer ${ }^{\mathrm{a} \bowtie}$, Helgi Arst ${ }^{\mathrm{a}}$, Tiina Nõges ${ }^{\mathrm{b}}$, and Lea Tuvikene ${ }^{\mathrm{b}}$ \\ ${ }^{a}$ Estonian Marine Institute, University of Tartu, Mäealuse 10a, 12618 Tallinn, Estonia \\ ${ }^{\mathrm{b}}$ Centre for Limnology, Institute of Agricultural and Environmental Sciences, Estonian University \\ of Life Sciences, 61117 Rannu, Tartumaa, Estonia \\ $\bowtie$ Corresponding author, tuuli.kauer@ut.ee
}

Received 20 March 2009, revised 18 September 2009

\begin{abstract}
Diurnal variation of the underwater quantum irradiance, the corresponding primary production profiles, and the integral primary production values were estimated by model calculations in three Estonian lakes (Peipsi, Võrtsjärv, and Harku) for 12 days in the summers of 2007 and 2008. In parallel, in situ measurements of primary production were carried out and the main bio-optical parameters of the water were determined. The concordance of the measured and modelled production profiles was satisfactory. Our results show that a model in which the initial data are daily variation of incoming irradiance in the PAR region combined with episodic measurements of chlorophyll $a$ concentration and diffuse attenuation coefficient in the water is suitable for estimating variation of primary production in lakes.
\end{abstract}

Key words: limnology of lakes, primary production, underwater light field, PAR, model calculations.

\section{INTRODUCTION}

Light provides the energy necessary for the transformation of inorganic matter into organic matter by the planktonic algae and all other photoautotrophic plants. Primary production is the direct product of photosynthesis, and primary productivity is the sum of all photosynthetic rates in an ecosystem (Fee, 1998). Information on the primary production enables to improve the understanding of food web relationships in aquatic ecosystems.

Because of changing light conditions, primary production has a pronounced diel pattern. In order to acquire integrated results over longer time periods (days, months, years), many consecutive measurements of instantaneous photosynthesis rate should be carried out and integrated. In some studies (Joniak et al., 2003; Yoshida et al., 2003; Forget et al., 2007) the values of daily primary production integrated over the photic zone were estimated from in situ incubations. However, such approach gives reliable results only in clear waters, while in highly productive waters incubation cannot be performed during a long period (e.g. from morning to evening) as part of the ${ }^{14} \mathrm{C}$-label gets lost from the cells during long-term incubation due to respiration of photosynthetic products (Lancelot \& Mathot, 1986) and release of extracellular products (Møller Jensen, 1985).

Bio-optical model calculations could provide an alternative to the timeconsuming ${ }^{14} \mathrm{C}$ method. Several studies estimate primary production from light 
T. Kauer et al.

intensity and abundance of phytoplankton pigments (cited in Arst et al., 2008a). In cases the processes of interest occur on a longer time-scale, it is common to ignore diurnal variations and use mean daily photosynthetically available irradiance (PAR) to force models of primary producers. Widely used methods include those where the dependence of photosynthesis on available light is expressed by an equation containing two parameters: the initial slope $\alpha^{\beta}$ and the assimilation number $P_{m}^{B}$ (Sathyendranath et al., 1989). In these models also data on the vertical profiles of the photosynthetically active radiation (PAR) $\left(\right.$ Einst $\left.\mathrm{h}^{-1} \mathrm{~m}^{-2}\right)$ are needed. This is a rather complicated way and gives results on the basis of radiation integrated over the PAR region. For reliable description of primary production profiles, however, it is preferable to use a 'spectral approach', in which the model is based on spectral data of underwater quantum irradiance and absorption coefficients of phytoplankton (Sathyendranath et al., 1989; Smith et al., 1989; Schofield et al., 1990; Kyewalyanga et al., 1992; Kirk, 1994; Sosik, 1996; Arst et al., 2006, 2008a).

Two versions (spectral and integral) of a semi-empirical model for calculation of the vertical profiles of primary production in lakes were elaborated by Arst et al. (2008a). The main difference between the models resides in the data on underwater irradiance (spectral or integral). Quantification of these models was performed using the data of in situ measurements of bio-optical parameters in three turbid Estonian lakes (Peipsi, Võrtsjärv, and Harku) in 2003-2005.

The objectives of the present study were (1) to demonstrate the variability of underwater quantum irradiance by calculating its spectral and diurnal variations at different depths of three lakes for all measurement days; (2) to compare in situ primary production measurement results obtained in 2007-2008 with corresponding model results; and (3) using model calculations to estimate the diurnal variability of the vertical profiles of primary production as well as the corresponding integrated (over water column) values.

\section{MATERIALS AND METHODS}

\section{Study sites}

The measurements were carried out in three Estonian lakes: Peipsi, Võrtsjärv, and Harku. Morphometric data and other parameters of the lakes are shown in Table 1.

Lake Peipsi is a large shallow lake on the border of Estonia and Russia. It is the fourth largest lake in Europe. According to the Estonian lake typology, Peipsi is a large unstratified eutrophic lake with oligohumic water of medium hardness (Jaani, 2001). The coordinates of our measurement point were approximately $58^{\circ} 50^{\prime} \mathrm{N}$ and $27^{\circ} 06^{\prime} \mathrm{E}$.

Lake Võrtsjärv is the largest lake situated entirely in Estonia. The geographical coordinates of its central point are about $58^{\circ} 13^{\prime} \mathrm{N}$ and $26^{\circ} 06^{\prime} \mathrm{E}$. Its water is optically turbid and underwater light climate is very strongly affected by the lake's water level and ice conditions (Reinart \& Nõges, 2004). Võrtsjärv is considered to be a hard-water eutrophic lake (Mäemets, 1977). 
Table 1. Morphometric data and the minimum and maximum values of some bio-optical parameters: Secchi depth $\left(z_{\mathrm{SD}}\right)$, averaged over PAR waveband diffuse attenuation coefficient $\left(K_{\mathrm{d}, \mathrm{PAR}}\right)$, and chlorophyll $a$ concentration $\left(C_{\mathrm{chl}}\right)$ in lakes Peipsi, Võrtsjärv, and Harku (Arst et al., 2008b; Paavel et al., 2008)

\begin{tabular}{lcccc}
\hline \multicolumn{1}{c|}{ Parameter } & Peipsi & Võrtsjärv & Harku \\
\hline Area, $\mathrm{km}^{2}$ & 2611 & 270 & 1.64 \\
Mean depth, $\mathrm{m}$ & 8.3 & 2.8 & 2 \\
Maximum depth, $\mathrm{m}$ & 12.9 & 6.0 & 2.5 \\
$z_{\mathrm{SD}}, \mathrm{m}$ & $0.4-4.8$ & $0.3-1.6$ & $0.1-1.0$ \\
$K_{\mathrm{d}, \mathrm{PAR}}, \mathrm{m}^{-1}$ & $0.74-2.58$ & $1.65-3.40$ & $2.50-7.70$ \\
$C_{\text {chl }}, \mathrm{mg} \mathrm{m}^{-3}$ & $1.8-95$ & $20-102$ & $54-389$
\end{tabular}

Lake Harku is located in North Estonia about $3 \mathrm{~km}$ from the coast of the Baltic Sea $\left(59^{\circ} 24^{\prime}\right.$ N, $24^{\circ} 37^{\prime}$ E). Hypertrophic Lake Harku is highly productive with medium-hard water of very low transparency (Mäemets, 1977; Arst et al., $2006 ; 2008 \mathrm{~b}$ ). Its water is warmed and mixed up to the bottom in summer.

\section{Database}

In the present study the initial data necessary for primary production calculations were collected in the summers of 2007 and 2008. The database contained the results of the following in situ and laboratory measurements:

- Incident solar irradiance for the PAR region $\left(q_{\text {PAR }}(z=+0)\right)$ was recorded from morning to evening beginning in May and finishing at the end of September (2007 and 2008). In Lake Võrtsjärv we used a Yanishevsky pyranometer (Kondratyev, 1965) placed on the roof of a building very close to the coastal station where the water samples were taken. For Lake Peipsi we got the necessary data from the actinometric station at Tiirikoja (on the western coast of Peipsi, close to the sampling point). In Lake Harku we measured the incident irradiance only on the measurement days (from morning to evening), using a LI-192 SA quantum sensor (LI-COR). From these data we determined the spectral values of irradiance for narrow spectral intervals $\Delta \lambda$ (width $10 \mathrm{~nm}$ ) in the region $400-700 \mathrm{~nm}$ as $q(\Delta \lambda, z=+0)=W(\Delta \lambda) q_{\mathrm{PAR}}(z=+0)$. Here $W(\Delta \lambda)$ is the contribution of each narrow spectral interval of irradiance in the PAR region (Bird \& Riordan, 1986).

- The spectral values of underwater planar quantum irradiance $(q(\lambda, z))$ were determined as $q(\Delta \lambda, z)=(1-r) q(\Delta \lambda, z=+0) \exp \left(-K_{\mathrm{d}}(\Delta \lambda) z\right)$ and later converted to scalar quantum irradiance $\left(q_{0}(\Delta \lambda, z)\right)$ according to Arst et al. (2008a). Here $r$ is the reflectance and $K_{\mathrm{d}}(\Delta \lambda)$ the spectral diffuse attenuation coefficient.

- The spectra of $K_{\mathrm{d}}(\Delta \lambda)$ were determined in two ways: (1) the spectral values for three channels of the spectroradiometer BIC-2104 (Biospherical Instruments Inc., 2003) were measured and then $K_{\mathrm{d}}(\Delta \lambda)$ in the region of $400-700 \mathrm{~nm}$ (for the intervals of $10 \mathrm{~nm}$ width) were calculated using the model by Paavel et al. (2006). The spectroradiometer BIC-2104 allows measuring the downwelling irradiance in three channels centred at 412, 555, and $665 \mathrm{~nm}\left(\right.$ in $\left.\mu \mathrm{mol} \mathrm{m}^{-2} \mathrm{~s}^{-1}\right)$; 
(2) using the spectra of the beam attenuation coefficient for filtered and unfiltered water samples in the wavelength range $350-700 \mathrm{~nm}$ measured by a Hitachi U3010 laboratory spectrophotometer. These results allow deriving the spectral values of $K_{\mathrm{d}}(\Delta \lambda)$ (Arst et al., 2002; Arst, 2003). In 2007 we used the results of BIC-2104 and Hitachi U3010, in 2008 only the Hitachi data.

- Relative transparency of water was measured with a Secchi disk $\left(z_{\mathrm{SD}}, \mathrm{m}\right)$. For concentrations of chlorophyll $a\left(C_{\mathrm{chl}}\right.$, in $\left.\mathrm{mg} \mathrm{m}^{-3}\right)$ water was filtered through Whatman GF/F-filters $(0.7 \mu \mathrm{m}$ pore size $)$ and the $C_{\text {chl }}$ were measured spectrophotometrically in ethanol extracts of the filters according to the ISO standard method (ISO 10260, 1992 (E)) and calculated by the Lorenzen (1967) method.

- To compare the computed profiles of primary production $(P(z$, calc $))$ with measured ones, we estimated $P(z$,meas $)$ in situ, usually at six different depths in the lake. We used the ${ }^{14} \mathrm{CO}_{2}$ assimilation technique (Steeman Nielsen, 1952) and a 2-h incubation around midday (the choice of the depths of incubation bottles depended on the transparency of the water). After incubation, the water was acidified $(\mathrm{pH}<2)$ with $0.5 \mathrm{~N} \mathrm{HCl}$ to remove the remaining inorganic ${ }^{14} \mathrm{C}$ (Niemi et al., 1983; Hilmer \& Bate, 1989; Lignell, 1992), then sample radioactivity was measured in an LSC RackBeta 1211 counter (Wallac, Finland) using external standardization for DPM calculations and Optiphase 'HiSafe 3' scintillation cocktail (Wallac, Finland). The standard formula (Nielsen \& Bresta, 1984) was used to calculate $P(z)$. Non-photosynthetic carbon fixation was measured in dark vials and subtracted from the light assimilation. As a result of these measurements we got 25 profiles of primary production.

\section{Short description of the model}

In the present work we used only the spectral model elaborated by Arst et al. (2008a). Our basic equation for the calculation of vertical profiles of primary production, $P(z)$, was the following:

$$
P(z)=\Psi Q_{\mathrm{PAR}}^{*}(z) F_{\mathrm{PAR}}(z),
$$

where $P(z)$ is in $\mathrm{mgC} \mathrm{m} \mathrm{m}^{-3} \mathrm{~h}^{-1}, \Psi$ is the factor 12000 for converting moles of carbon to milligrams of carbon, $Q_{\mathrm{PAR}}^{*}(z)$ is photosynthetically absorbed radiation at depth $z$ determined on the basis of scalar quantum irradiance (in Einst $\mathrm{m}^{-3} \mathrm{~h}^{-1}$ ), and $F_{\text {PAR }}(z)$ is the quantum yield of carbon fixation $\left(\mathrm{mol} \mathrm{C} \mathrm{Einst}{ }^{-1}\right)$. The index PAR means that the variables were determined for the range of $400-700 \mathrm{~nm}$. The parameter $Q_{\mathrm{PAR}}^{*}(z)$ was calculated in the following way (Arst et al., 2008a):

$$
Q_{\mathrm{PAR}}^{*}(z)=\int_{400}^{700} q_{0}(\lambda, z) a_{\mathrm{ph}}^{\prime}(\lambda) C_{\mathrm{chl}} d \lambda
$$

where $q_{0}(\lambda, z)$ is underwater scalar quantum irradiance, $C_{\mathrm{chl}}$ is the concentration of chlorophyll $a$, and $a_{\mathrm{ph}}^{\prime}(\lambda)$ is the specific absorption coefficient of phytoplankton obtained as an average for some typical species combinations. 
For the determination of the parameter $a_{\mathrm{ph}}^{\prime}(\lambda)$ we used an algorithm presented by Bricaud et al. (1995):

$$
a_{\mathrm{ph}}^{\prime}(\lambda)=A(\lambda) C_{\mathrm{chl}}^{-B(\lambda)}
$$

where the specific absorption coefficient $a_{\mathrm{ph}}^{\prime}(\lambda)$ is calculated taking into account the 'package effect' (Morel \& Bricaud, 1981; Kirk, 1994; Bricaud et al., 1995); $A$ and $B$ are positive, wavelength-dependent parameters, as tabulated in Bricaud et al. (1995).

The quantum yield of carbon fixation, $F_{\mathrm{PAR}}(z)$, was calculated on the basis of the algorithm derived and tested in Arst et al. (2008a):

$$
F_{\mathrm{PAR}}(z)=\frac{F_{\max }}{\left(1+M q_{0, \mathrm{PAR}}(z)\right)^{n}},
$$

where $F_{\max }=0.08$ mol C Einst ${ }^{-1}, q_{0, \mathrm{PAR}}(z)$ is the scalar quantum irradiance at the depth $z$ (in Einst $\mathrm{m}^{-2} \mathrm{~h}^{-1}$ ), $M$ and $n$ are the parameters that depended on incident irradiance as well as on the bio-optical characteristics of the water body.

The quantification of $n$ and $M$ was performed using the database of the years 2003-2005 (Arst et al., 2008a). For the values of $K_{\mathrm{d}, \mathrm{PAR}}$ from 0.7 to $7 \mathrm{~m}^{-1}$ a constant value $n=3$ was obtained, but the coefficient $M$ varied in each individual case. Tests of different versions (using regression analysis) led us to conclude that our dataset needed to be divided into three groups according to chlorophyll $a$ content. In Group $1 C_{\text {chl }}$ was from 4 to $35 \mathrm{mg} \mathrm{m}^{-3}$; in group 2 it was from 35.1 to $100 \mathrm{mg} \mathrm{m}^{-3}$; and in Group $3 C_{\mathrm{chl}}>100 \mathrm{mg} \mathrm{m}^{-3}$. Applying multiple regression analysis we got suitable equations for $M$, but only for groups 1 and 2 . These multiple regression equations and respective statistical parameters are presented in Table 2. In the conditions of very high $C_{\text {chl }}$ values (Group 3) no good regression between $M$ and the water properties was found; however, a constant value of $M=0.18$ turned out to be suitable for this group.

It should be noted that Eq. 3 and its parameters $A(\lambda)$ and $B(\lambda)$ (Bricaud et al., 1995) were derived on the basis of data for small and moderate values of $C_{\mathrm{chl}}$. For this reason we should improve our model, collecting the spectra of $a_{\mathrm{ph}}^{\prime}(\lambda)$ for high values of $C_{\mathrm{chl}}$ (we plan to do it in the future). However, through quantifying the models, the choice of the parameters in the algorithms can to some extent compensate for the influence of inappropriate absorption spectra (regression analysis in Arst et al., 2008a).

Table 2. Regression formulas for the parameter $M$ (in Eq. 4) for the spectral model of primary production (taken from Arst et al., 2008a). In these formulas $q_{\mathrm{PAR}}(z=0)$ is in Einst $\mathrm{m}^{-2} \mathrm{~h}^{-1}, C_{\text {chl }}$ in $\mathrm{mg} \mathrm{m}^{-3}$, and $K_{\mathrm{d}, \mathrm{PAR}}$ in $\mathrm{m}^{-1}$. $\mathrm{N}$ is the number of measurement series

\begin{tabular}{l|c|c|c|c|c}
\hline Group & $M$ & $R^{2}$ & $\mathrm{SE}$ & $p$ & $\mathrm{~N}$ \\
\hline 1 & $0.97-0.0036 q_{\mathrm{PAR}}(z=0)-0.067 K_{\mathrm{d}, \mathrm{PAR}}^{2.5}$ & 0.831 & 0.11 & $<0.0001$ & 15 \\
2 & $0.80-0.077 q_{\mathrm{PAR}}(z=0)-0.00066 C_{\mathrm{chl}}$ & 0.713 & 0.07 & $<0.0001$ & 26
\end{tabular}


T. Kauer et al.

\section{RESULTS}

\section{Comparison of measured and calculated primary production profiles}

Our next step was comparison of the measured and calculated primary production $(P(z))$ profiles. Some examples are presented in Fig. 1(a,b,c).

(a)

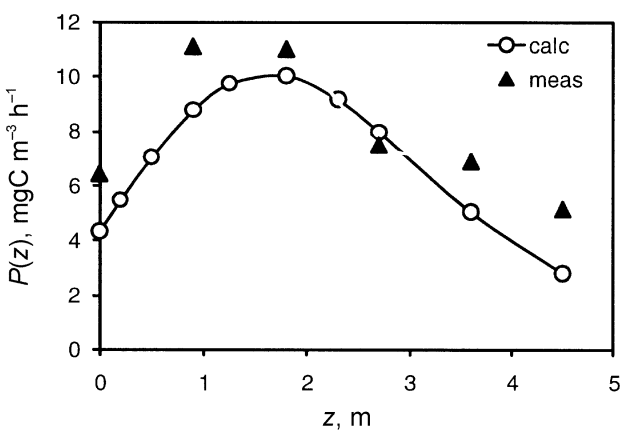

(b)

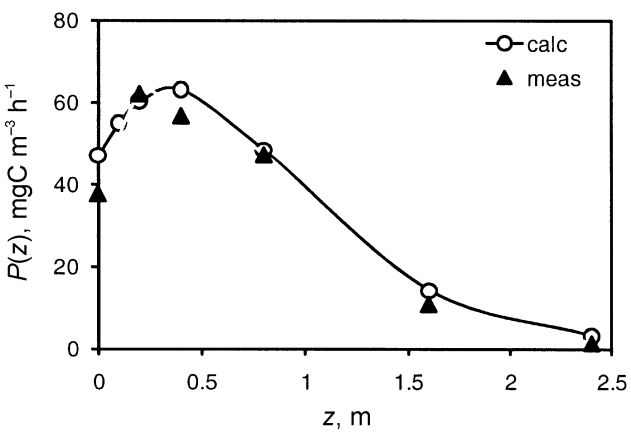

(c)

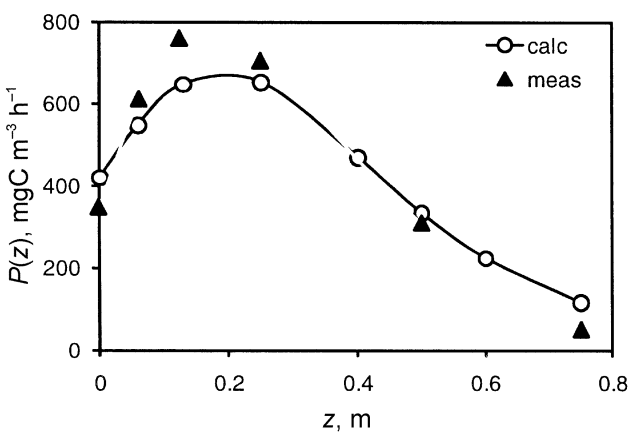

Fig. 1. Comparison of measured and calculated profiles of the primary production in (a) Lake Peipsi 27.06.2008, (b) Lake Vorrtsjärv 15.05.2007, and (c) Lake Harku 23.07.2008. The values of $C_{\text {chl }}$ were $8.8,45$, and $155 \mathrm{mg} \mathrm{m}^{-3} ; q_{\mathrm{PAR}}(z=0)$ was 734,432 , and $1530 \mu \mathrm{mol} \mathrm{m}^{-2} \mathrm{~s}^{-1}$, respectively. Measurements were performed around midday. 
The coincidence of $P$ (meas) and $P($ calc) shown in Fig. 1(a,b,c) is rather good, but there exist also results where it is considerably worse. The best way for estimating the concordance of measured and calculated results is the regression $P$ (meas) vs. $P($ calc). Figure 2 shows the regression for all three lakes studied (25 profiles in 2007-2008). However, this figure describes lakes Võrtsjärv and Peipsi very poorly, because for these lakes almost all values of $P(z)$ were below $200 \mathrm{mgC} \mathrm{m}^{-3} \mathrm{~h}^{-1}$. In Fig. 3 the regression is shown only for lakes Võrtsjärv and Peipsi. According to these results, the concordance of measured and calculated primary production is satisfactory, the determination coefficients were 0.873 and 0.879 , respectively.

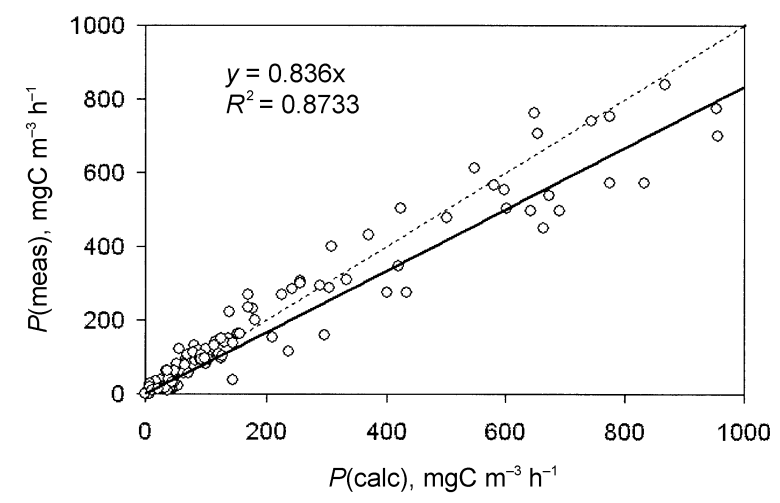

Fig. 2. Regression $P$ (meas) vs. $P($ calc) obtained in 2007-2008 for all three lakes (intercept was taken equal to zero). $\mathrm{SE}=72 \mathrm{mgC} \mathrm{m}^{-3} \mathrm{~h}^{-1}, p<0.0001, N=134$ (obtained from 25 profiles of primary production).

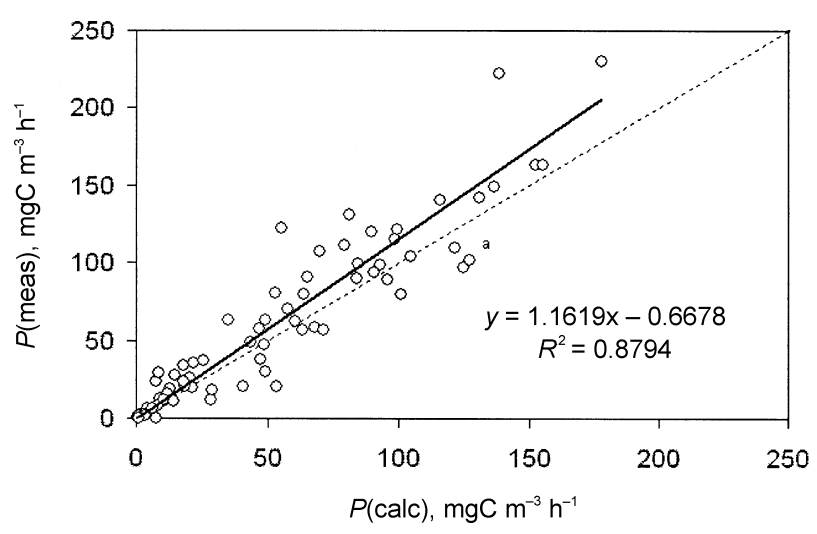

Fig. 3. Regression $P$ (meas) vs. $P($ calc) obtained in 2007-2008 for lakes Peipsi and Võrtsjärv. $\mathrm{SE}=21 \mathrm{mgC} \mathrm{m}^{-3} \mathrm{~h}^{-1}, p<0.0001, N=76$ (obtained from 13 profiles of primary production). 
T. Kauer et al.

In Arst et al. (2008a) the regression $P$ (meas) vs. $P$ (calc) was determined for lakes Peipsi and Võrtsjärv (together) on the basis of data obtained in 2003-2005. According to these results $P($ meas $)=0.99 P($ calc $)+0.31, R^{2}=0.92, \mathrm{SE}=11$, $N=241$. However, in 2007-2008 we had a considerably smaller database $(N=76)$, which possibly explains the smaller value of $R^{2}$.

\section{Diurnal variability of underwater irradiance and primary production}

In the present study we calculated the diurnal variation of the underwater quantum irradiance and the corresponding primary production profiles during 12 summer days. Below we demonstrate the variability of underwater quantum irradiance for two days at three depths (Figs 4 and 5).

In these figures the $x$-axes show the time, and on the $y$-axes the wavelength and the values of underwater quantum irradiance are presented using the colour scale near each figure (the scales are the same in both figures). These colours describe the variation of the values of irradiance and there is nothing in common with the colours of solar spectrum. In both cases a marked influence of cloudiness on the underwater light field can be seen (a repeated interchange of the colours during the day); without clouds the diurnal change of the irradiance should be monotonous. With increasing depth the influence of cloudiness weakened slightly. On 17 July 2007, illustrated in Fig. 4, the weather was sunny up to midday, but afterwards the irradiance decreased rapidly due to considerable cloudiness. Figure 5 demonstrates variable cloudiness throughout the day. Changes of the colours from red to blue show a drop of irradiance due to decreasing incident solar irradiance (mornings and evenings) and increasing depth (light attenuation in the lake water).

Some examples of primary production in dependence on depth and time $(t)$ are shown in Figs 6 and 7. Similarly to irradiance, the values of $P(z, t)$ are characterized using a colour scale. Figures 6 and 7 demonstrate expressively the dependence of primary production on the illumination conditions (solar zenith angle and cloudiness). In the case of clear weather we could follow also the increase of $P(z)$ from the 'inhibition minimum' to its maximum value and after this the decrease of $P(z)$ with increasing depth. In cloudy days and in the conditions of low illumination the maximum of $P(z)$ was located near the water surface even at midday.

In addition to the vertical profiles of $P(z)$, we calculated the integral values, $P_{\text {int }}$, using for this integration of $P(z)$ over depth. These results can only be considered as approximations for two reasons. First, the first bottle was located about $5 \mathrm{~cm}$ below the surface, not just under it, and at the maximum depth of measurements, $P(z)$, was not zero, but had some small value. Second, $P_{\text {int }}$ was calculated using the trapezoidal rule, which somewhat underestimated $P_{\text {int }}$ in comparison with real values. However, the results obtained were good enough for comparison of $P_{\text {int }}$ in different lakes. The diurnal variation of $P_{\text {int }}$ is presented in Fig. 8 (we chose three cases, one for each lake). 


\section{Estimation of phytoplankton productivity}
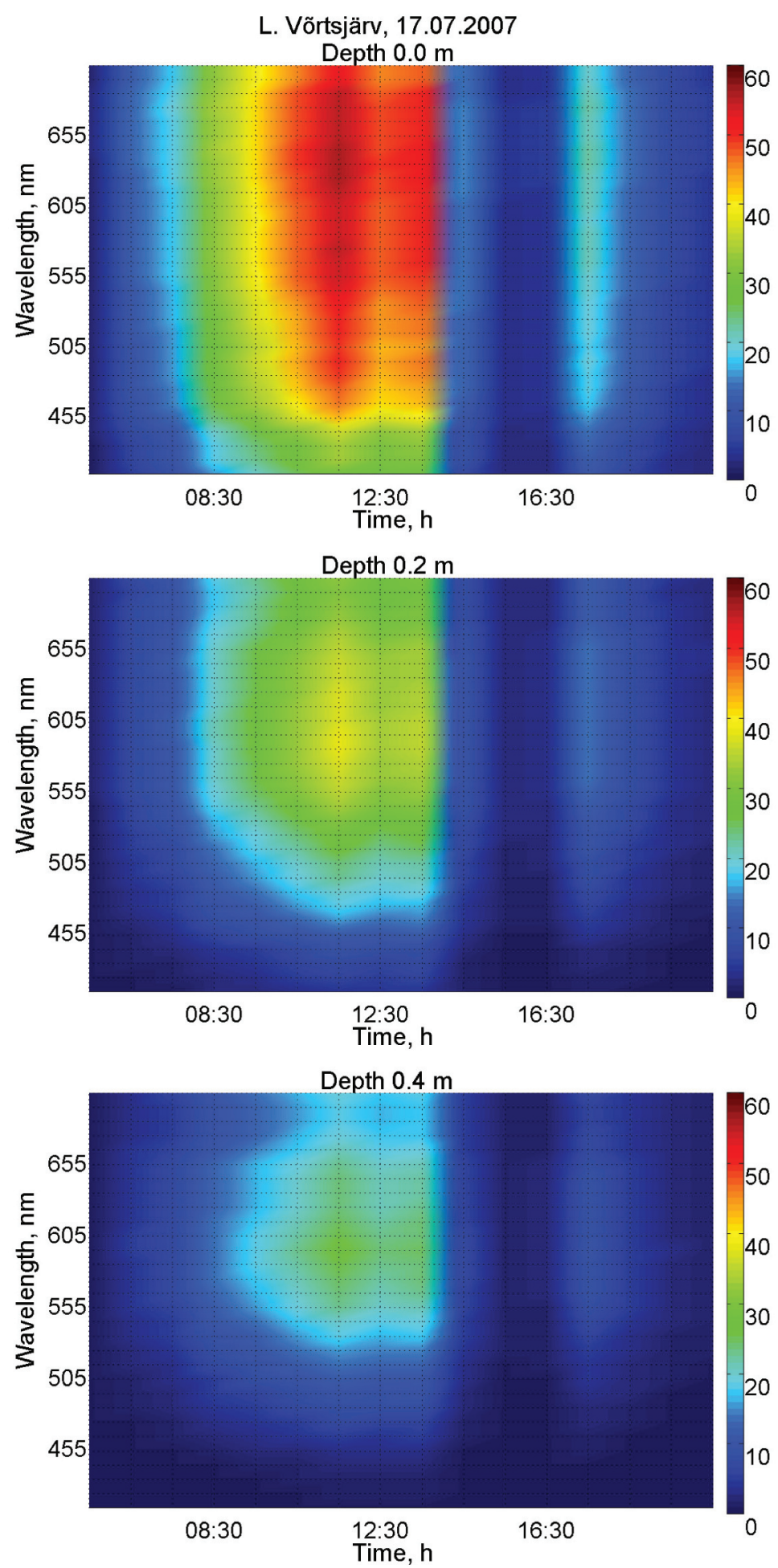

Fig. 4. Variation of the spectral quantum irradiance $q(\lambda, t, z)$ from morning to evening in Lake Võrtsjärv. 
T. Kauer et al.
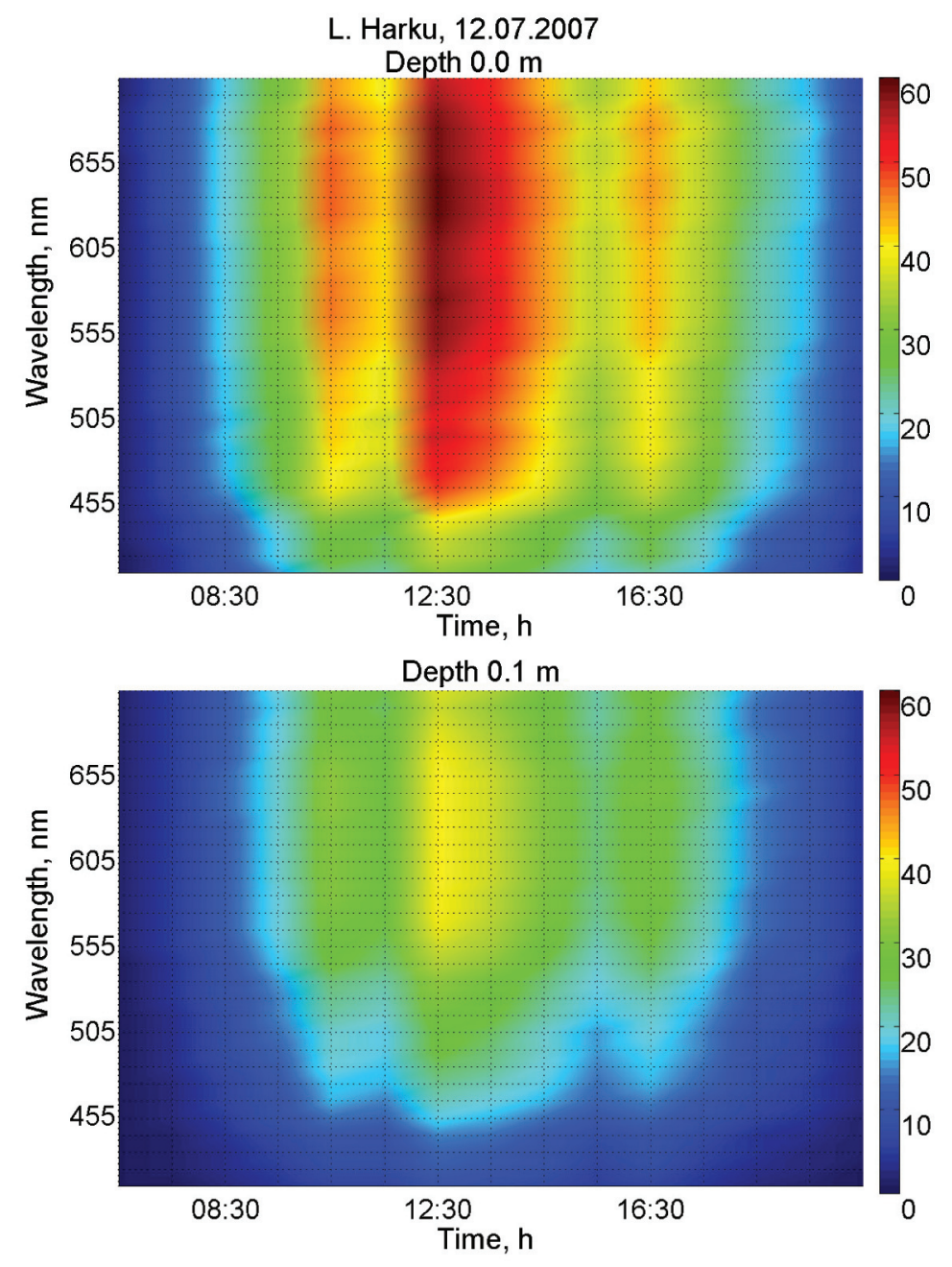

Depth $0.2 \mathrm{~m}$

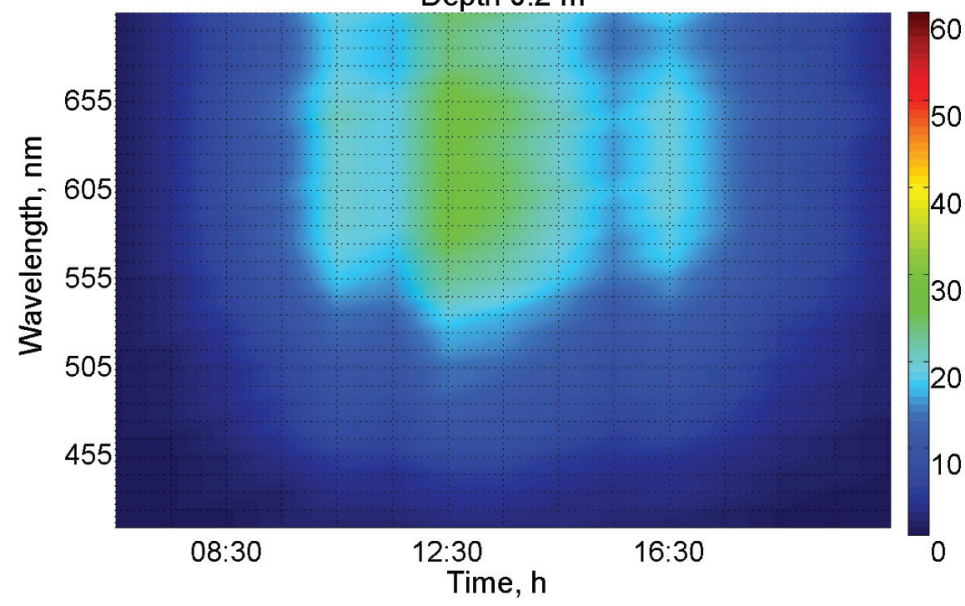

Fig. 5. Variation of the spectral quantum irradiance $q(\lambda, t, z)$ from morning to evening in Lake Harku. 306 


\section{Estimation of phytoplankton productivity}

(a)

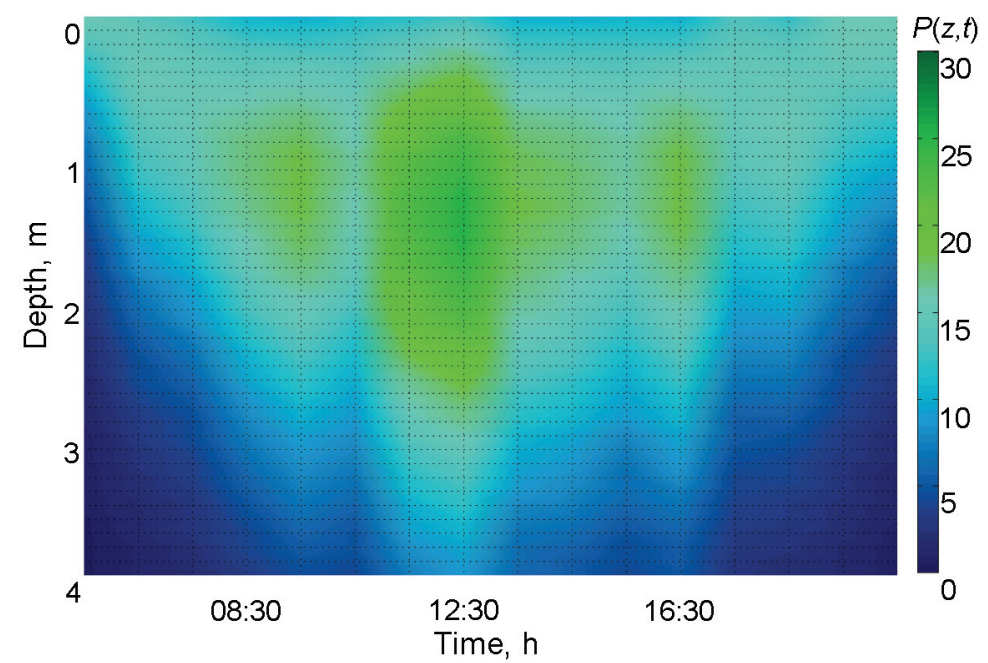

(b)

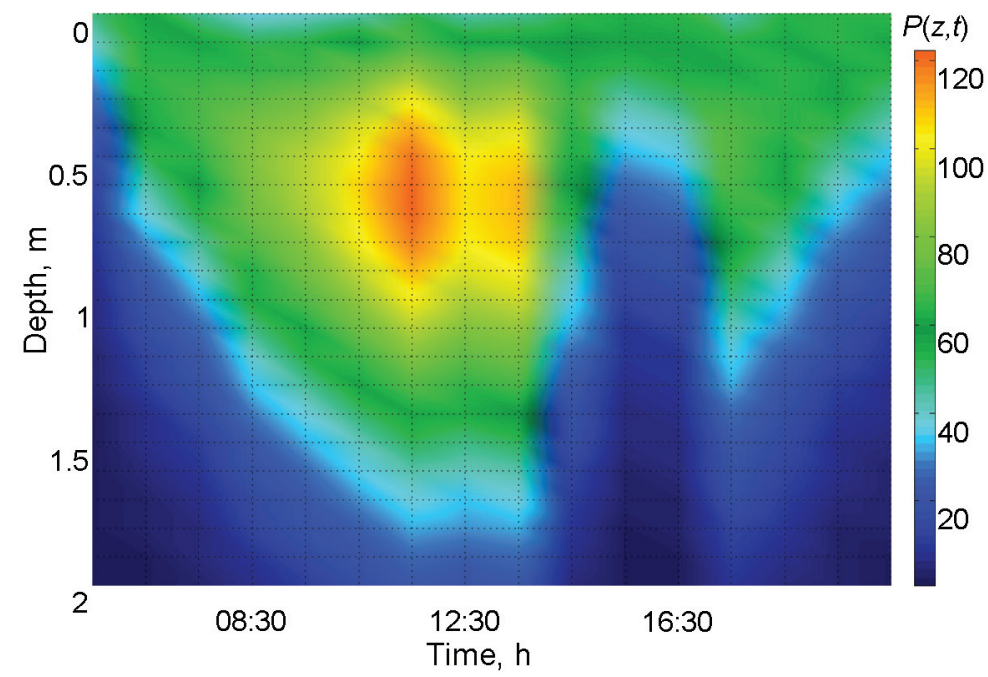

Fig. 6. Primary production $P(z, t)$ in dependence of time and depth for (a) Lake Peipsi on 27 June 2008, $C_{\mathrm{Chl}}=8.8 \mathrm{mg} \mathrm{m}^{-3}$ and (b) Lake Vortsjärv on 17 July 2007, $C_{\mathrm{Chl}}=43 \mathrm{mg} \mathrm{m}^{-3}$. In both cases there was variable cloudiness. 
T. Kauer et al.

(a)

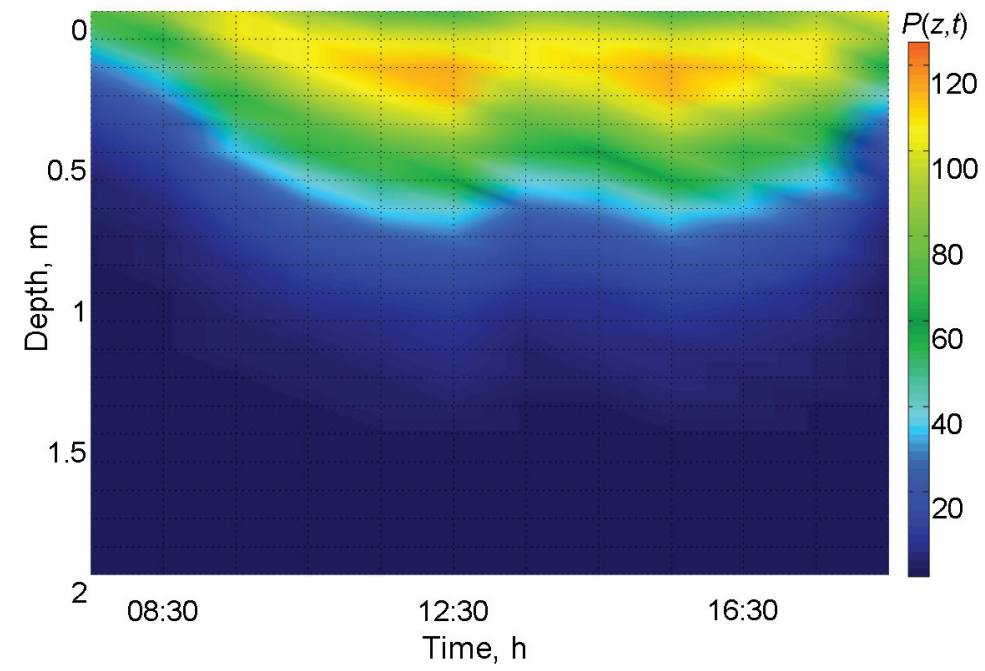

(b)

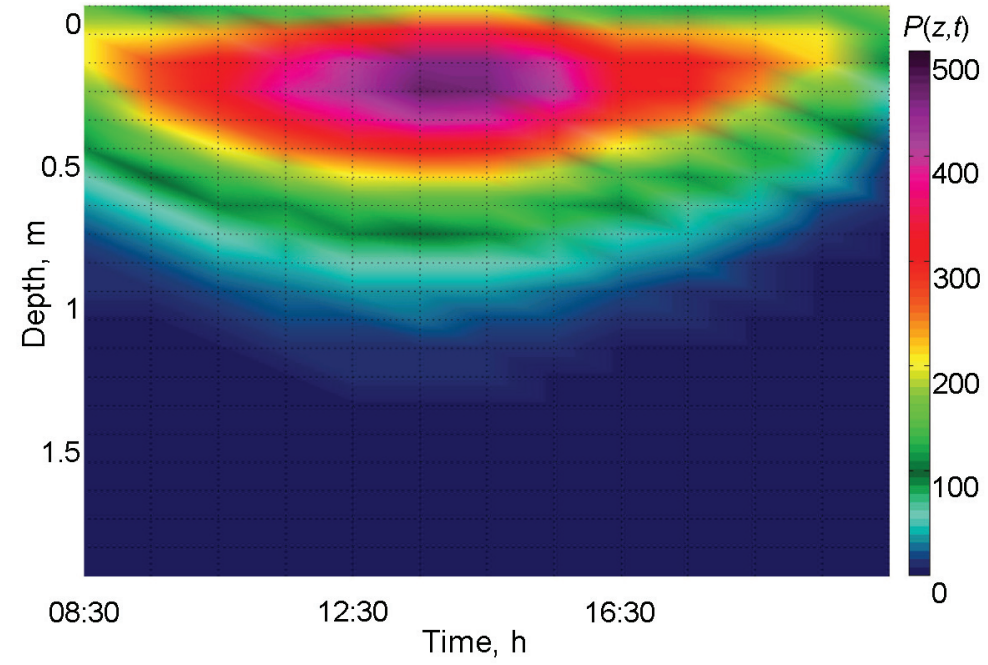

Fig. 7. Primary production $P(z, t)$ in dependence of time and depth for (a) Lake Vorrtsjärv on 17 September 2007 (cloudy weather, low illumination), $C_{\mathrm{Chl}}=82 \mathrm{mg} \mathrm{m}^{-3}$ and (b) Lake Harku on 23 July $2008, C_{\mathrm{Chl}}=155 \mathrm{mg} \mathrm{m}^{-3}$ (in general sunny weather with some clouds in the afternoon). 


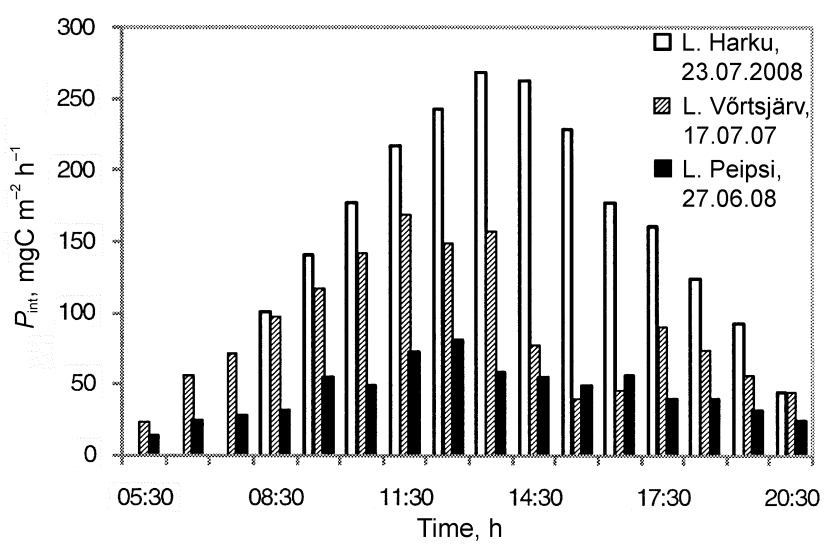

Fig. 8. Diurnal variation of $P_{\text {int }}$. The times 5:30, 7:30 etc. express the hourly averages of $P_{\text {int }}$ from 5:00 to $6: 00$, from 7:00 to $8: 00$, etc.

These results allow calculating the diurnal sums of integral primary production for all three cases: for Lake Peipsi on 27 June 2008 it was $711 \mathrm{mgC} \mathrm{m}^{-2}$ day $^{-1}$, for Võrtsjärv on 17 July 2007 it was $1410 \mathrm{mgC} \mathrm{m}^{-2}$ day $^{-1}$, and for Lake Harku on 23 July 2008 it was $2237 \mathrm{mgC} \mathrm{m}^{-2}$ day $^{-1}$. Note that for lakes Peipsi and Võrtsjärv the hourly averages of $P_{\text {int }}$ were summarized from 5:00 to 21:00, but for Lake Harku from 8:00 to 21:00.

\section{DISCUSSION}

The results obtained in our study can be compared only with few other publications. We did not find any paper containing a detailed description of the profiles of primary production during a day, as it is shown in our study. There are numerous studies where the estimation of the daily/monthly sums and their seasonal variation (on the basis of episodic measurements connected with theoretical knowledge) was carried out in marine environments as well as in lakes (Fee, 1980; Tillmann et al., 2000; Joniak et al., 2003; Yoshida et al., 2003; Davies et al., 2004; Nõges \& Kangro, 2005; Demidov, 2008). Robson (2005) studied the effects of diurnal variations in light on primary production at a seasonal time-scale. The variation of phytoplankton production is explained mainly with availability of nutrients (Schindler, 1978), $C_{\text {chl }}$ (Tillmann et al., 2000; Demidov, 2008), and light limitation (Kyewalyanga et al., 1992; Tillmann et al., 2000). This is in concordance with our main conclusion that there are three main factors forming the profiles and diurnal sums of the primary production: incoming irradiance, chlorophyll content, and attenuation coefficient of light in the water.

It should be noted that Eq. 3 and its parameters $A(\lambda)$ and $B(\lambda)$ (Bricaud et al., 1995) were derived on the basis of data for small and moderate values of $C_{\mathrm{chl}}$. However, through quantifying the models, the choice of the parameters in the algorithms can to some extent compensate for the influence of inappropriate absorption spectra (regression analysis in Arst et al., 2008a). 
T. Kauer et al.

There are some ways for improving the calculations of primary production described above. First, the daily recording of spectral and vertical distribution of the underwater irradiance should be carried out with an underwater spectrophotometer giving the full spectrum between 400 and $700 \mathrm{~nm}$. Second, we need reliable, synthesized data on the specific absorption coefficients of phytoplankton in the turbid water bodies, which would allow us to requantify our primary production model.

\section{CONCLUSIONS}

The results obtained demonstrate the suitability of the model by Arst et al. (2008a) for detailed description of vertical and temporal variation of the underwater quantum irradiance as well as primary production in lakes. However, when the purpose is to get a large number of results (daily variations during the whole summer, monthly sums, etc.), the calculations are rather time-consuming, and elaboration of an automatized computing system is urgently needed.

Our results demonstrate a strong dependence of irradiance and primary production profiles on cloudiness, which brings about their irregular diurnal variation (sometimes with several maximums and minimums) and a special form of vertical profile of primary production (maximum production at the surface) in the conditions of an overcast sky.

The results obtained confirm the conclusion that there are three main factors forming the profiles and diurnal sums of primary production: incoming solar irradiance, chlorophyll content, and attenuation coefficient of light in the water.

\section{ACKNOWLEDGEMENTS}

The authors are indebted to the Estonian Ministry of Education and Research (target-financed projects 03962480s03, 0712699s05, and 0170011s08) and the Estonian Science Foundation (grant 7156) for financial support to this investigation, and to M. Hussainov, T. Feldmann, and E. Lill for their help with field measurements and laboratory analyses.

\section{REFERENCES}

Arst, H. 2003. Optical Properties and Remote Sensing of Multicomponental Water Bodies. Springer \& Praxis-Publishing, Chichester, UK.

Arst, H., Erm, A., Reinart, A., Sipelgas, L. \& Herlevi, A. 2002. Calculating irradiance penetration into water bodies from the measured beam attenuation coefficient II: Application of improved model to different types of lakes. Nord. Hydrol., 33, 207-226.

Arst, H., Erm, A., Kangro, K., Nõges, T. \& Nõges, P. 2006. Comparison of spectral and broad-band models for computing photosynthetically absorbed radiation in turbid waters. Bor. Environ. Res., 11, 55-65.

Arst, H., Nõges, T., Nõges, P. \& Paavel, B. 2008a. In situ measurements and model calculations of primary production in turbid waters. Aquat. Biol., 3, 19-30. 
Arst, H., Nõges, T., Nõges, P. \& Paavel, B. 2008b. Relations of phytoplankton in situ primary production, chlorophyll concentration and underwater irradiance in turbid lakes. Hydrobiologia (Special issue: European Large Lakes), 599, 169-176.

Bird, R. E. \& Riordan, C. 1986. Simple solar spectral model for direct and diffuse irradiance on horizontal and tilted planes at earth's surface for cloudless atmospheres. J. Climate Appl. Meteorol., 25, 87-97.

Bricaud, A., Babin, M., Morel, A. \& Claustre, H. 1995. Variability in the chlorophyll-specific absorption coefficients of natural phytoplankton: analysis and parametrization. J. Geophys. Res., 100(C7), 13321-13332.

Davies, J.-M., Nowlin, W. H. \& Mazumder, A. 2004. Variation in temporal $\left[{ }^{14} \mathrm{C}\right]$ plankton photosynthesis among warm monomictic lakes of coastal British Columbia. J. Plankt. Res., 26(7), 763-778.

Demidov, A. B. 2008. Seasonal dynamics and estimation of the annual primary production of phytoplankton in the Black Sea. Oceanology, 48, 664-678.

Fee, E. J. 1980. Important factors for estimating annual phytoplankton production in the experimental Lakes Area. Can. J. Fish. Aquat. Sci., 37, 513-522.

Fee, E. J. 1998. Computer programs for calculating in situ phytoplankton photosynthesis. Canadian Technical Report of Fisheries and Aquatic Sciences, No. 1740. Revised Web version http://www.umanitoba.ca/institutes/fisheries/PSpgms.html (accessed 25.12.2007).

Forget, M.-H., Sathyendranath, S., Platt, T., Pommier, J., Vis, C., Kyewalyanga, M. \& Hudson, C. 2007. Extraction of photosynthesis-irradiance parameters from phytoplankton production data: demonstration in various aquatic systems. J. Plankt. Res., 29(3), 249-262.

Hilmer, T. \& Bate, G. C. 1989. Filter types, filtration and post-filtration treatment in phytoplankton production studies. J. Plankt. Res., 11(1), 49-63.

ISO 10260. 1992 (E). Water Quality - Measurement of Biochemical Parameters - Spectrophotometric Determination of Chlorophyll a Concentration. Geneva, Switzerland.

Jaani, A. 2001. The location, size and general characterization of Lake Peipsi and its catchment area. In Lake Peipsi. Meteorology, Hydrology, Hydrochemistry (Nõges, T., ed.), pp. 10-17. Sulemees Publishers, Tartu.

Joniak, T., Gołdyn, R. \& Kozak, A. 2003. The primary production of phytoplankton in the restored Maltañski Reservoir in Poland. Hydrobiologia, 506-509, 311-316.

Kirk, J. T. O. 1994. Light and Photosynthesis in Aquatic Ecosystems. Cambridge University Press.

Kondratyev, K. Ya. 1965. Actinometry. Gidrometeoizdat, Leningrad (in Russian).

Kyewalyanga, M., Platt, T. \& Sathyendranath, S. 1992. Ocean primary production calculated by spectral and broad-band models. Mar. Ecol. Prog. Ser., 85, 171-185.

Lancelot, C. \& Mathot, S. 1986. Biochemical fractionation of primary production by phytoplankton in Belgian coastal waters during short- and long-term incubations with ${ }^{14} \mathrm{C}$-bicarbonate. Mar. Biol., 86(3), 219-226.

Lignell, R. 1992. Problems in filtration fractionation of ${ }^{14} \mathrm{C}$ primary productivity samples. Limnol. Oceanogr., 37, 172-178.

Lorenzen, C. J. 1967. Determination of chlorophyll and phaeopigments; spectrophotometric equations. Limnol. Oceanogr., 12, 343-346.

Mäemets, A. 1977. Eesti NSV järved ja nende kaitse. Valgus, Tallinn.

Møller Jensen, L. 1985. ${ }^{14}$ C-labelling patterns of phytoplankton: specific activity of different product pools. J. Plankt. Res., 7(5), 643-652.

Morel, A. \& Bricaud, A. 1981. Theoretical results concerning light absorption in a discrete medium, and application to specific absorption of phytoplankton. Deep Sea Res., 28, 1375-1393.

Niemi, M., Kuparinen, J., Uusi-Rauva, A. \& Korhonen, K. 1983. Preparation of algal samples for liquid scintillation counting. Hydrobiologia, 106, 149-159.

Nielsen, G. A. \& Bresta, A. M. (eds) 1984. Guidelines for the Measurement of Phytoplankton Primary Production. 2nd edn. Publ. 1. The Baltic Marine Biologists, Charlottenlund.

Nõges, T. \& Kangro, K. 2005. Primary production of phytoplankton in a strongly stratified temperate lake. Hydrobiologia, 547, 105-122. 
T. Kauer et al.

Paavel, B., Arst, H., Reinart, A. \& Herlevi, A. 2006. Model calculations of diffuse attenuation coefficient spectra in lake waters. Proc. Estonian Acad. Sci. Biol. Ecol., 55, 61-81.

Paavel, B., Arst, H. \& Reinart, A. 2008. Variability of bio-optical parameters in two North-European large lakes. Hydrobiologia (Special issue: European Large Lakes), 599, 201-211.

Reinart, A. \& Nõges, P. 2004. Light conditions in Lake Võrtsjärv. In Lake Võrtsjärv (Haberman, J., Pihu, E. \& Raukas, A., eds), pp. 141-149. Estonian Encyclopaedia Publishers, Tallinn.

Robson, B. J. 2005. Representing the effects of diurnal variations in light on primary production on a seasonal time-scale. Ecol. Model., 186, 358-365.

Sathyendranath, S., Platt, T., Caverhill, C. M., Warnock, R. E. \& Lewis, M. R. 1989. Remote sensing of oceanic primary production: computations using a spectral model. Deep Sea Res., 36, 431-453.

Schindler, D. W. 1978. Factors regulating phytoplankton production and standing crop in the world's freshwaters. Limnol. Oceanogr., 23, 478-486.

Schofield, O., Bidigare, R. R. \& Prézelin, B. B. 1990. Spectral photosynthesis, quantum yield and blue-green light enchancement of productivity rates in the diatom Chaetoceros gracile and the pryemnesiophyte Emiliana huxleyi. Mar. Ecol. Prog. Ser., 64, 175-186.

Smith, R. C., Prézelin, B. B., Bidigare, R. R. \& Baker, K. S. 1989. Bio-optical modeling of photosynthetic production in coastal waters. Limnol. Oceanogr., 34, 1524-1544.

Sosik, H. M. 1996. Bio-optical modelling of primary production: consequences of variability in quantum yield and specific absorption. Mar. Ecol. Prog. Ser., 143, 225-238.

Steeman Nielsen, E. 1952. The use of radioactive carbon $\left({ }^{14} \mathrm{C}\right)$ for measuring primary production in the sea. J. Cons. Int. Explor. Mer., 18, 117-140.

Tillmann, U., Hesse, K.-H. \& Coljin, F. 2000. Planktonic primary production in the German Wadden Sea. J. Plankt. Res., 22(7), 1253-1276.

Yoshida, T., Sekino, T., Genkai-Kato, M., Logacheva, N. P., Bondarenko, N. A., Kawabata, Z., Khodzher, T. V., Melnik, N. G., Hino, S., Nozaki, K., Nishimura, Y., Nagata, T., Higashi, M. $\&$ Nakanishi, M. 2003. Seasonal dynamics of primary production in the pelagic zone of southern Lake Baikal. Limnology (Jap. Soc. Limnol.), 4, 53-62.

\title{
Fütoplanktoni produktiivsuse hindamine kolmes Eesti järves
}

\author{
Tuuli Kauer, Helgi Arst, Tiina Nõges ja Lea Tuvikene
}

Mudelarvutuste abil hinnati veealuse kiiritustiheduse päevaseid käike, primaarproduktsiooni vertikaalseid profiile ja integraalse primaarproduktsiooni päevast muutlikkust kolmes Eesti järves (Peipsi järv, Võrtsjärv ning Harku järv) 2007. ja 2008. aasta suvel. Mudelarvutusteks vajalikud lähteandmed saadi in situ kiirgusmõõtmiste ja veeproovide laboratoorse töötluse abil. Paralleelselt viidi in situ läbi episoodilisi primaarproduktsiooni mõõtmisi (21 mõõtepäeva), saadud profiile (25) võrreldi mudelarvutuste vastavate tulemustega. Selline võrdlus näitas mõõdetud ja arvutatud tulemuste head kokkulangevust. Töö põhijärelduseks on, et mudel, mille algandmeteks on pidevalt registreeritud pealelangev kiiritustihedus fotosünteetiliselt aktiivses spektripiirkonnas, episoodiliselt mõõdetud klorofüll $a$ kontsentratsioon ja valguse difuusne nõrgenemiskoefitsient, sobib primaarproduktsiooni muutlikkuse hindamiseks järvedes. 